\title{
Kadar Bilirubin, Alkalin Fosfatase, dan Gamma Glutamil Transpeptidase Serum sebagai Prediktor Batu Duktus Koledokus pada Pasien Batu Empedu Simtomatik
}

\author{
${ }^{1}$ Maria Kaunang, ${ }^{2}$ Jimmy Panelewen, ${ }^{2}$ Toar Mambu \\ ${ }^{1}$ PPDS Ilmu Bedah Fakultas Kedokteran Universitas Sam Ratulangi Manado \\ ${ }^{2}$ Divisi Bedah Digestif Bagian Ilmu Bedah Universitas Sam Ratulangi/RSUP Prof. Dr. R. D. \\ Kandou Manado \\ Email: yuna_nx@yahoo.com
}

\begin{abstract}
Complications of the common bile duct stone occur in 10-15\% of patients with gallstones. Bilirubin, alkaline phosphatase (ALP), and gamma glutamyl transpeptidase (GGT) are routine laboratory tests performed on patients with gallstones. This study was aimed to determine whether bilirubin, ALP, and GGT serum could be used as predictors of common bile duct stone in patient with symptomatic gallstone at Prof. Dr. R. D. Kandou Hospital Manado and its satellite hospitals. This was a prospective analytical observational study with a cross sectional design. Subjects were 38 patients with symptomatic gallstone that underwent definitive surgery. The bilirubin, ALP, and GGT serum levels were taken at presentation. Receiver operating characteristic curve analysis was used to determine optimal biochemical cut-off value of each parameter. The results showed that of 38 patients, 22 patients were male and 16 patients were female. The mean ages were 52 years in males and 47 years in females. There were 28 patients proven to have stones in common bile ducts. All parameters were proven to be effective in predicting common bile duct stone, as follows: bilirubin cut-off point was $1.6 \mathrm{U} / \mathrm{L}$ with sensitivity of $96.4 \%$ and specifity of $90 \%$; ALP cut-off point was $114 \mathrm{U} / \mathrm{L}$ with sensitivity of $82.1 \%$ and specifity of $90 \%$; and GGT cut-off point was $102.5 \mathrm{U} / \mathrm{L}$ with sensitivity of $85.7 \%$ and specifity of $90 \%$. Conclusion: Bilirubin, ALP, and GGT serum levels can be used as predictors of common bile duct stone in patient with symptomatic gallstone.
\end{abstract}

Keywords: bilirubin, ALP, GGT, common bile duct stone

\begin{abstract}
Abstrak: Komplikasi batu duktus koledokus terjadi pada 10-15\% pasien dengan batu empedu. Bilirubin, alkalin fosfatase (ALP), and gamma glutamil transpeptidase (GGT) merupakan pemeriksaan laboratorium rutin pada pasien dengan batu empedu. Penelitian ini bertujuan untuk menentukan apakah bilirubin, ALP, dan GGT serum dapat dipakai sebagai prediktor batu duktus koledokus pada pasien dengan batu empedu simtomatik di RSUP Prof. Dr. R. D. Kandou Manado dan rumah sakit jejaringnya. Jenis penelitian ialah observasional analitik prospektif dengan desain potong lintang. Pemeriksaan kadar bilirubin, ALP, dan GGT serum dilakukan pada semua subyek saat didiagnosis batu empedu simtomatik. Receiver operating characteristic curve analysis digunakan untuk menentukan nilai titik potong biokimia yang optimal dari setiap parameter. Hasil penelitian mendapatkan sebanyak 38 pasien dengan batu empedu simtomatik yang menjalani operasi definitif, terdiri dari 22 pasien laki-laki and 16 pasien perempuan. Rerata usia subyek ialah 52 tahun pada laki-laki dan 47 tahun pada perempuan. Terdapat 28 pasien terbukti dengan batu duktus koledokus. Semua parameter terbukti efektif dalam memrediksi batu doktus koledokus sebagai berikut: titik potong bilirubin serum 1,6 U/L dengan sensitivitas $96,4 \%$ and spesifitas $90 \%$; titik potong ALP serum $114 \mathrm{U} / \mathrm{L}$ dengan sensitivitas $82,1 \%$ dan spesifitas $90 \%$; titik potong GGT serum 102,5 U/L dengan sensitivitas $85,7 \%$ dan spesifitas $90 \%$. Simpulan: Kadar bilirubin, ALP, dan GGT serum dapat dipakai sebagai prediktor batu duktus koledokus pada pasien dengan batu empedu simtomatik.
\end{abstract}

Keywords: bilirubin, ALP, GGT, batu duktus koledokus 
Batu empedu merupakan penyakit yang sering ditemukan pada penduduk di belahan bumi bagian Barat. ${ }^{1}$ Prevalensi batu empedu di Amerika sekitar 15\% dari populasi penduduk atau sekitar 20 juta penderita. ${ }^{2}$ Gejala dan komplikasi batu empedu merupakan penyakit di Bagian Digestif yang paling merugikan dengan biaya hampir mencapai 6,5 milyar dolar per tahun. ${ }^{1}$ Pada sekitar $10-15 \%$ pasien dengan batu empedu terdapat komplikasi batu duktus koledokus. $^{3}$

Walaupun belum terdapat konsensus, sebagian besar klinisi berpendapat bahwa batu dalam duktus koledokus harus dikeluarkan karena risiko tinggi terjadinya komplikasinya seperti kolangitis dan pankreatitis akut. ${ }^{4-6}$ Bilirubin, alkalin fosfatase (ALP), dan gamma glutamil transpeptidase (GGT) merupakan pemeriksaan rutin yang dilakukan pada pasien dengan batu empedu. Beberapa penelitian menunjukkan bahwa kadar bilirubin, ALP, dan GGT dapat memrediksi adanya batu duktus koledokus pada pasien dengan batu empedu simtomatik. $^{7-11}$

Penelitian ini bertujuan untuk mengetahui akurasi kadar bilirubin, ALP, dan GGT serum dalam memrediksi batu duktus koledokus pada pasien dengan batu empedu simptomatik di RSUP Prof. Dr. R. D. Kandau Manado dan RS jejaringnya.

\section{METODE PENELITIAN}

Penelitian ini merupakan penelitian observasional analitik dengan desain potong lintang. Populasi penelitian ialah pasien dengan batu empedu simtomatik di RSUP Prof. Dr. R. D. Kandou Manado dan RS jejaring. Subyek penelitian ialah pasien dengan batu empedu simtomatik di RSUP Prof. Dr. R. D. Kandou dan RS jejaring yang menjalani prosedur endoscopic retrograde cholangiopancreatography (ERCP), atau eksplorasi duktus koledokus baik secara laparoskopik maupun terbuka, atau hasil laparoskopik kolesistektomi dan intraoperative cholangiogram (IOC), serta memenuhi kriteria inklusi.

Penelitian ini dilakukan di RSUP Prof. Dr. R. D. Kandou Manado sejak bulan
Maret 2018 s/d September 2018. Pemeriksaan kadar bilirubin, ALP dan GGT serum dilakukan pada semua subyek pada saat didiagnosis batu empedu simtomatik.

Analisis data menggunakan metode analisis regresi logistik dan untuk menentukan area under the curve (AUC) dan titik potong masing-masing dari bilirubin, ALP, dan GGT serum digunakan kurva Receiver Operating Characterictic (ROC).

\section{HASIL PENELITIAN}

Pada penelitian ini didapatkan sebanyak 38 pasien yang memenuhi kriteria inklusi dan menjadi subyek penelitian, terdiri dari 22 orang laki-laki $(57,90 \%)$ dan 16 orang perempuan $(42,10 \%)$. Rerata usia ialah 50,32 tahun, dengan rerata pada lakilaki 52,4 tahun dan rerata pada perempuan 47,9 tahun. Rentang usia ialah 35-79 tahun. Sebanyak 3 pasien $(7,89 \%)$ mempunyai modalitas pencitraan USG abdomen saja, 24 pasien $(63,16 \%)$ dengan USG dan $C T$ Scan abdomen, serta 11 pasien $(28,94 \%)$ dengan pencitraan USG dan magnetic resonance cholangiopancreatography (MRCP). Jenis operasi yang dilakukan ialah ERCP 11 pasien (28,94\%); LCBDE 12 pasien (31,58\%); open exploration of CBD 4 pasien $(10,52 \%) ;$ laparascopic cholecyst-ectomy dan IOC 10 pasien $(26,31 \%)$; dan LCBDE konversi open 1 pasien (2.63\%) (Tabel 1).

Pada pengukuran kadar bilirubin serum didapatkan rerata $6,6692 \mathrm{U} / \mathrm{L}$, nilai tengah $5,0400 \mathrm{U} / \mathrm{L}$, nilai terendah $0,32 \mathrm{U} / \mathrm{L}$, dan nilai tertinggi $27,83 \mathrm{U} / \mathrm{L} \quad(\mathrm{SD} \pm 7,29874$ U/L) (Tabel 2). Pada pengujian kadar bilirubin dengan metode regresi logistik didapatkan nilai $P=0,021 \quad(<0,05)$, yang berarti bilirubin serum dapat digunakan sebagai prediktor batu duktus koledokus.

Pada pengukuran kadar ALP serum didapatkan rerata $175,92 \mathrm{U} / \mathrm{L}$, nilai tengah 142,00 U/L, terendah $49 \mathrm{U} / \mathrm{L}$, dan tertinggi 459 U/L (SD $\pm 103,600$ U/L) (Tabel 3). Pada pengujian kadar ALP serum dengan metode regresi logistik didapatkan nilai $P=0,017(<0,05)$, yang berarti ALP serum dapat digunakan sebagai prediktor batu duktus koledokus. 
Tabel 1. Data deskriptif umum dari subyek penelitian

\begin{tabular}{lc}
\hline \multicolumn{1}{c}{ Data } & Hasil \\
\hline Jenis kelamin & \\
Laki-laki & $22(57,90 \%)$ \\
Perempuan & $16(42,10 \%)$ \\
Usia & 50,32 tahun \\
Rerata (mean) & 52,40 tahun \\
Laki-laki & 47,94 tahun \\
Perempuan & 35 tahun \\
Termuda & 79 tahun \\
Tertua & \\
Pencitraan: & $3(7,89 \%)$ \\
USG abdomen & $24(63,16 \%)$ \\
USG + CT Scan abdomen & $11(28,94 \%)$ \\
USG + MRCP & \\
Jenis operasi: & $11(28,94 \%)$ \\
ERCP & $12(31,58 \%)$ \\
LCBDE & $10(26,31 \%)$ \\
LC+IOC & $4(10,52 \%)$ \\
Open exploration CBD & $1(2,63 \%)$ \\
LCBDE konversi open &
\end{tabular}

Pada pengukuran kadar GGT serum didapatkan rerata $263,47 \mathrm{U} / \mathrm{L}$, nilai tengah
175,00 U/L, kadar terendah $20 \mathrm{U} / \mathrm{L}$, dan kadar tertinggi $883 \mathrm{U} / \mathrm{L}(\mathrm{SD} \pm 244,060 \mathrm{U} / \mathrm{L})$ (Tabel 4). Pada pengujian kadar GGT dengan metode regresi logistik didapatkan nilai $P=0,010 \quad(<0,05)$ yang berarti GGT serum dapat digunakan sebagai prediktor batu duktus koledokus.

Dengan demikian, kadar bilirubin, ALP, dan GGT serum dapat digunakan untuk penentuan nilai diagnostik batu duktus koledokus. Titik potong ditentukan dengan kurva ROC. Berdasarkan analisis ROC diperoleh AUC kadar bilirubin serum ialah 0,954>0,700 yang menunjukkan penentuan nilai diagnosis batu duktus koleduktus berdasarkan kadar bilirubin serum dapat digunakan dan diperoleh titik potong kadar bilirubin serum 1,605 U/L (Gambar 1). Berdasarkan titik potong ini didapatkan: nilai sensitivitas $96,4 \%$, nilai spesifisitas $90 \%$, nilai prediksi positif $96,4 \%$, nilai prediktif negatif $90 \%$, dan memiliki OR 243,0 dengan interval kepercayaan (IK 95\%) 13,7-4297,1.

Tabel 2. Klasifikasi pasien berdasarkan nilai titik potong bilirubin serum

\begin{tabular}{cccc}
\hline $\begin{array}{c}\text { Bilirubin } \\
(\mathrm{U} / \mathrm{L})\end{array}$ & \multicolumn{2}{c}{ Batu duktus koledokus } & Total \\
\hline$\geq 1,605$ & Ya & Tidak & \\
$<1,605$ & 27 & 1 & 28 \\
Total & 28 & 9 & 10 \\
\hline
\end{tabular}

Tabel 3. Klasifikasi pasien berdasarkan titik potong ALP serum

\begin{tabular}{cccc}
\hline ALP & \multicolumn{2}{c}{ Batu duktus koledokus } & Total \\
$(\mathrm{U} / \mathrm{L})$ & Ya & Tidak & \\
\hline$\geq 114$ & 23 & 1 & 24 \\
$<114$ & 5 & 9 & 14 \\
Total & 28 & 10 & 38 \\
\hline
\end{tabular}

Tabel 4. Klasifikasi pasien berdasarkan titik potong GGT serum

\begin{tabular}{cccc}
\hline GGT & \multicolumn{2}{c}{ Batu Duktus Koledokus } & Total \\
$(\mathrm{U} / \mathrm{L})$ & Ya & Tidak & \\
\hline$\geq 102,5$ & 24 & 1 & 25 \\
$<102,5$ & 4 & 9 & 13 \\
Total & 28 & 10 & 38 \\
\hline
\end{tabular}


Berdasarkan analisis ROC diperoleh AUC kadar ALP serum ialah 0,895 > 0,700 , yang menunjukkan penentuan nilai diagnosis batu duktus koleduktus berdasarkan kadar ALP serum dapat digunakan dan diperoleh titik potong kadar ALP serum $114 \mathrm{U} / \mathrm{L}$ (Gambar 2). Berdasarkan titik potong ini didapatkan: nilai sensitivitas $82,1 \%$, nilai spesifisitas $90,0 \%$, nilai prediksi positif $95,8 \%$, nilai prediksi negatif 64,3\%, dan memiliki OR 41,4 dengan interval kepercayaan (IK 95\%) 4,2-405,2.

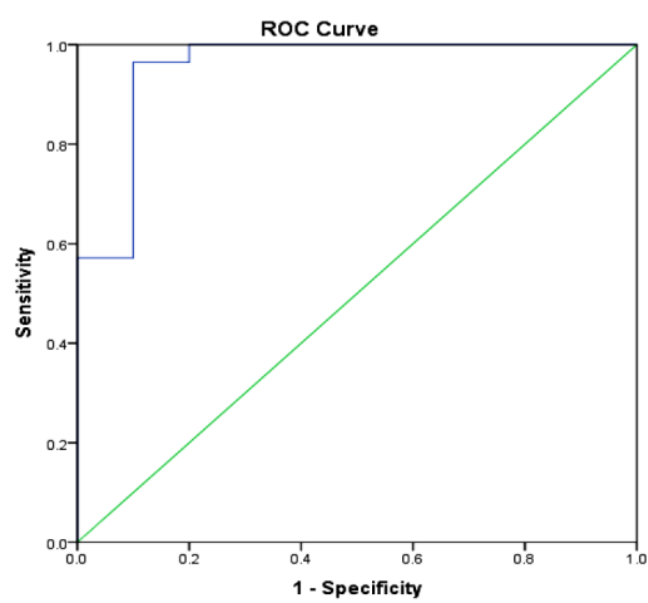

Gambar 1. Kurva ROC bilirubin serum

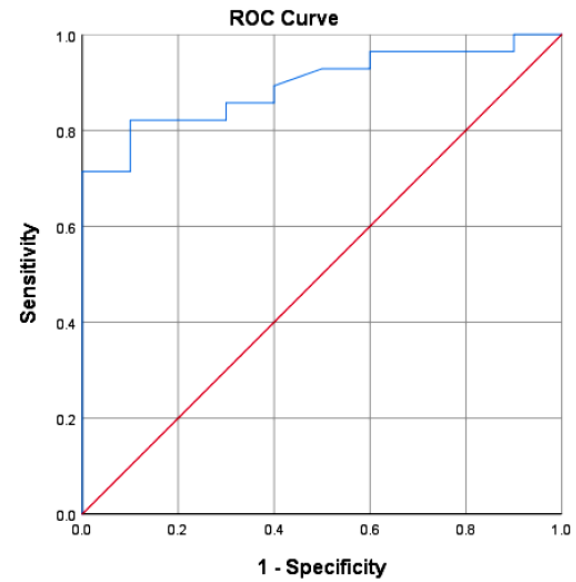

Gambar 2. Kurva ROC ALP serum

Berdasarkan analisis ROC diperoleh AUC kadar GGT serum ialah 0,891 >0,700. Hasil ini menunjukkan bahwa penentuan nilai diagnosis batu duktus koleduktus berdasarkan kadar GGT serum dapat digunakan dan diperoleh titik potong kadar
GGT serum 102,5 U/L. Berdasarkan titik potong ini didapatkan: nilai sensitivitas $85,7 \%$, nilai spesifisitas $90,0 \%$, nilai prediksi positif $96,0 \%$, nilai prediksi negatif $69,2 \%$, dan memiliki OR 54,0 dengan interval kepercayaan (IK 95\%) 5,3-550,2.

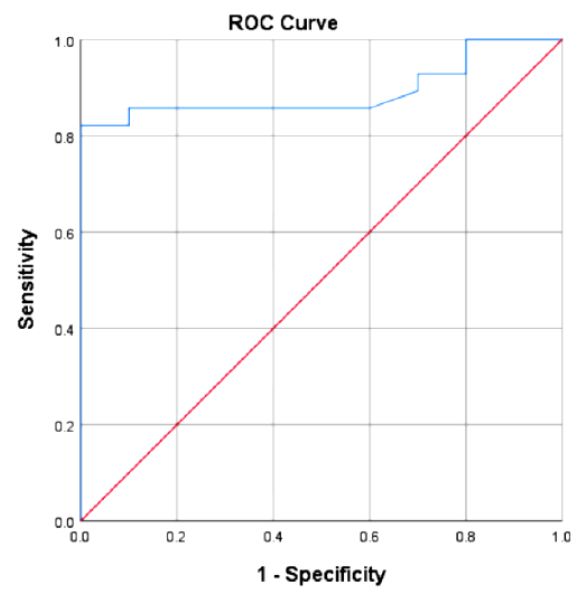

Gambar 4. Kurva ROC GGT serum

\section{BAHASAN}

Batu empedu merupakan salah satu masalah saluran cerna yang paling sering ditemukan. Komplikasi batu duktus koledokus pada pasien dengan batu empedu meningkatkan morbiditas dan mortalitas secara signifikan dan pada populasi Asia komplikasi ini mencapai 3-15\%.

Data epidemiologi menunjukkan bahwa batu empedu mengenai perempuan lebih sering daripada laki-laki, terutama pada masa subur. Kemungkinan perempuan mendapat batu empedu hampir 2 kali dibandingkan laki-laki, akan tetapi akan berkurang sesuai pertambahan usia. Hal ini dihubungkan dengan hormon, kehamilan, penggunaan kontrasepsi oral, dan terapi estrogen. Estrogen meningkatkan sekresi kolesterol dan mengurangi sekresi garam empedu, sedangkan progestin mengurangi sekresi garam empedu dan mengganggu pengosongan kandung empedu yang mengakibatkan stasis. ${ }^{13}$ Pada penelitian ini didapatkan pasien laki-laki $(57,9 \%)$ lebih banyak dibandingkan perempuan $(42,1 \%)$. Hal ini dapat disebabkan karena jumlah subyek penelitian ini kurang besar (hanya 37 pasien).

Rentang usia pada pasien dalam pene- 
litian ini didapatkan termuda 35 tahun dan tertua 79 tahun dengan rerata 50 tahun, Pada pasien laki-laki reratanya lebih tinggi yaitu usia 52,4 tahun sedangkan rerata pada perempuan 47,9 tahun. Temuan ini sejalan dengan studi-studi lainnya bahwa batu empedu sering ditemukan pada pasien dewasa usia pertengahan. ${ }^{1-3,13}$

Pada penelitian ini didapatkan sebanyak $7,89 \%$ pasien mempunyai modalitas pencitraan USG abdomen saja, 63,16\% pasien dengan USG dan CT Scan abdomen, dan $28,94 \%$ pasien dengan pencitraan USG dan MRCP. Penunjang dasar yaitu USG abdomen dikerjakan pada semua pasien. Adanya batu pada kantung empedu dalam USG abdomen merupakan syarat mutlak untuk pemilihan pasien. Pemilihan penunjang selanjutnya disesuaikan dengan kondisi pasien, dapat dilakukan pemeriksaan penunjang lain seperti $C T$ scan abdomen atau MRCP. Jenis operasi yang dilakukan ialah ERCP $(28,94 \%)$, LCBDE (31,58\%), open exploration of CBD $(10,52 \%)$, laparascopic cholecystectomy dan IOC (26,31\%), dan LCBDE konversi open $(2,63 \%)$. Pasien dengan batu kandung empedu saja dilakukan laparoskopik kolesistektomi disertai IOC untuk memastikan patologi pada saluran bilier dan ada tidaknya batu pada saluran bilier. Pada pasien dengan batu kandung empedu dengan kecurigaan adanya batu duktus koledokus, terdapat alternatif tindakan. Pemilihan dilakukan ERCP antara lain ialah pada pencitraan terlihat batu di bagian distal duktus koledokus, sedangkan eksplorasi duktus koledokus, baik secara laparoskopik ataupun terbuka dipilih berdasarkan kondisi pasien dan ketersediaan sumber daya yang dimiliki saat itu.

Pada pengujian kadar bilirubin dengan metode regresi logistik didapatkan nilai signifikansi $P=0,02(<0.05)$ sehingga kadar bilirubin dapat digunakan sebagai prediktor batu duktus koledokus. Hasil analisis ROC mendapatkan titik potong kadar bilirubin serum 1,605. Berdasarkan titik potong ini diperoleh: nilai sensitivitas $96,4 \%$, nilai spesifisitas $90 \%$, nilai prediksi positif $96,4 \%$, dan nilai prediktif negatif $90 \%$.
Nilai-nilai ini lebih tinggi dibandingkan dengan hasil penelitian oleh Barkun et al ${ }^{11}$ yang mendapatkan nilai sensitivitas $74 \%$ dan spesifitas $48 \%$ pada nilai titik potong bilirubin yang lebih tinggi yaitu $30 \mu \mathrm{mol} / \mathrm{L}$ atau $1,754 \mathrm{U} / \mathrm{L}$ pada 139 pasien yang dilakukan ERCP sebelum dilakukan laparoskopik kolesistektomi. Penelitian lain oleh Kama et al $^{10}$ pada 48 pasien batu duktus koledokus mendapatkan nilai sensitivitas $73 \%$ dan spesifitas $92 \%$ pada nilai titik potong yang lebih rendah yaitu $20 \mu \mathrm{mol} / \mathrm{L}$ atau 1,169 U/L. Penelitian lainnya juga melaporkan nilai yang bervariasi, tetapi kebanyakan bersimpulan bahwa kadar bilirubin merupakan prediktor kuat untuk batu duktus koledokus. ${ }^{14}$ Bahkan dalam rekomendasinya, American Society of Gastrointestinal Endoscopy (ASGE) menempatkan kadar bilirubin 1,8-4 mg/dL sebagai prediktor kuat sedangkan kadar bilirubin $>4 \mathrm{mg} / \mathrm{dL}$ sebagai prediktor sangat kuat untuk memrediksi adanya batu duktus koledokus. ${ }^{15}$.

Pada pengujian kadar ALP serum dengan metode regresi logistik didapatkan nilai signifikansi $P=0,017<0,05$, yang berarti dapat digunakan sebagai prediktor batu duktus koledokus. Hasil analisis ROC mendapatkan titik potong kadar serum alkalin fosfatase 114 U/L dengan sensitivitas $82,1 \%$, spesifisitas $90,0 \%$, nilai prediksi positif $95,8 \%$, dan nilai rediksi negatif $64,3 \%$. Penelitian oleh Barkun et $\mathrm{al}^{11}$ mendapatkan titik potong yang jauh lebih tinggi yaitu $300 \mathrm{U} / \mathrm{L}$ tetapi dengan sensitivitas dan spesifitas yang lebih rendah yaitu $79 \%$ dan $35 \%$. Al-Jiffry et al ${ }^{6}$ meneliti 109 pasien dengan batu duktus koledokus dan menemukan bahwa kadar ALP >300 U/L akan meningkatkan kemungkinan terdapatnya batu duktus koledokus sebanyak 30x lipat dibandingkan dengan yang mempunyai kadar ALP normal. Kedua penelitian di atas melibatkan lebih banyak sampel dibandingkan penelitian kami.

Pada pengujian kadar GGT dengan metode regresi logistik didapatkan nilai signifikansi $P=0,01<0,05$ yang berarti kadar GGT serum dapat digunakan sebagai prediktor batu duktus koledokus. Hasil 
analisis ROC diperoleh titik potong kadar GGT serum 102,5 U/L. Berdasarkan titik potong ini diperoleh: nilai sensitivitas $85,7 \%$, spesifisitas $90,0 \%$, nilai prediksi positif $96,0 \%$ dan nilai prediksi negatif $69,2 \%$. Penelitian oleh Peng et $\mathrm{al}^{16}$ pada pasien dengan kolesistitis akut akibat kolelitiasis mendapatkan titik potong GGT pada $90 \mathrm{U} / \mathrm{L}$ untuk memrediksi adanya batu duktus koledokus dengan sensitivitas $86 \%$ dan spesifitas $74,5 \%$. Yang et $\mathrm{al}^{17}$ mendapatkan sensitivitas $84,1 \%$ dan spesifitas $72 \%$ dari kadar GGT darah dalam memrediksi adanya batu duktus koledokus pada 1002 pasien yang akan dilakukan laparoskopik kolesistektomi. Hasil tersebut melampaui nilai sensitivitas dan spesifitas bilirubin dan ALP pada pasien yang sama. Penelitian lainnya oleh Gill ${ }^{18}$ melaporkan bahwa GGT sebagai prediktor lebih kuat untuk memrediksi batu duktus koledokus pada pasien dengan penyakit bilier yang ikterik maupun non-ikterik, dibandingkan dengan ALP maupun 5-nukleotidase.

Penelitian-penelitian pembanding di atas menunjukkan hasil yang bervariasi terhadap akurasi ketiga penanda biokimia batu duktus koledokus. Hal tersebut dapat disebabkan oleh berbagai faktor, antara lain karakteristik sampel yang dipilih, metode penelitian dan analisis, dan faktor-faktor lain yang bisa menjadi bias, misalnya adanya penyakit penyerta lain.

Pada penelitian ini didapatkan sensitivitas dan spesifitas yang cukup tinggi bila dibandingkan dengan hasil penelitian yang berasal dari luar negeri, sementara data penelitian pembanding yang dilakukan di Indonesia belum ada. Kelebihan penelitian ini ialah penelitian prospektif, sehingga pemilihan pasien dan data yang diperoleh lebih presisi sedangkan kelemahannya ialah menggunakan desain potong lintang.

\section{SIMPULAN}

Berdasarkan hasil penelitian ini dapat disimpulkan bahwa kadar bilirubin, alkalin fosfatase, dan gamma glutamil transpeptidase serum dapat digunakan sebagai prediktor batu duktus koledokus pada pasien dengan batu empedu simptomatik.

\section{DAFTAR PUSTAKA}

1. Ko CW, Lee SP. Epidemiology and natural history of common bile duct stones and prediction of disease. Gastrointest Endosc. 2002;56:S165.

2. Everhart JE, Ruhl CE. Burden of digestive diseases in United States. Part III: liver, biliary tract and pancreas. Gastroenterology. 2009;136:1134-44.

3. Ko CW, Lee SP. Gallstones. In: Tadataka Y, editor. Textbook of Gastroenterology Vol 1 (5th ed). New Jersey: WilleyBlackwell Publishing, 2009; p. 195277.

4. Prat F, Meduri B, Chiche B, Salimbeni R, Pelletiert G. Prediction of common bile duct stones by noninvasive tests. Ann Surg. 1999;229(3):362-8.

5. Canena J. Once upon a time a guideline was used for the evaluation of suspected choledocholithiasis: A fairy tale or a nightmare? GE Port J Gastroenterol. 2018;25:6-9.

6. Al-Jiffry B, Elfateh A, Chundrigar T, Othman B, AlMalki O, Rayza F, et al. Non-invasive assessment of choledocholithiasis in patients with gallstones and abnormal liver function. World J Gastroenterol. 2013;19(35): 5877-82.

7. Wang CH, Mo LR, Lin RC, K uo JY, Chang KK. Rapid diagnosis of choledocholithiasis using biochemistry tests in patients undergoing laparoscopic cholecystectomy. HepatoGastroenterology. 2001;48:619-21

8. Onken JE, Brazer SR, Eisen GM, Williams DM, Bouras EP, DeLong ER, et al. Predicting the presence of choledocholithiasis in patients with symptomatic cholelithiasis. Am J Gastroenterol. 1996;91(4):762-7.

9. Barr LL, Frame BC, Coulanjon A. Proposed criteria for preoperative endoscopic retrograde cholangiography in candidates for laparoscopic cholecystectomy. Surg Endosc. 1999;13(8):778-81.

10. Kama NA, Atli M, Doganay M, Kologlu M, Reis E, Dolapci M. Practical recommendations for the prediction and management of common bile duct stones in patients with gallstones. Surg Endosc. 2001;15:942-5. 
11. Barkun AN, Barkun JS, Fried GM, Ghitulescu G, Steinmetz O, Pham C, et al. Useful predictors of bile duct stones in patients undergoing laparoscopic cholecystectomy. Ann Surg. 1994;220(1):32-9.

12. Aslam HM, Salem S, Edhi MM, Shaikh HA, Khan JD, Hafiz M, et al. Assessment of gallstone predictor: comparative analysis of ultrasonographic and biochemical parameters. Int Arch Med. 2013;6:17.

13. Stinton LM, Shaffer EA. Epidemiology of gallbladder disease: cholelithiasis and cancer. Gut and Liver. 2012;6(2):17287.

14. Bose SM, Mazumdar A, Prakash VS, Kocher R, Katariya S, Pathak CM. Evaluation of the Predictors of choledocholithiasis: comparative analysis of clinical, biochemical, radiological, radionuclear, and intraoperative parameters. Surg Today. 2001;31:117-22.
15. ASGE Standards of Practice Committee, Maple JT, Ben-Menachem T, Anderson MA, Appalaneni V, Banerjee S, et al. The role of endoscopy in the evaluation of suspected choledocholithiasis. Gastrointest endosc. 2010;71(1):1-9.

16. Peng WK, Sheikh Z, Paterson BS. Role of liver function tests in predicting common bile duct stones in acute calculous cholecystitis. BJS. 2005;92: 1241-7.

17. Yang MH, Chen TH, Wang SE, Tsai YF, Su CH, Wu CW, et al. Biochemical predictors for absence of common bile duct stones in patients undergoing laparoscopic cholecystectomy. Surg Endosc. 2008;22(7):1620-4.

18. Gill MPS. Comparative study of serum gamma glutamyltransferase, 5' nucleotidase and alkaline phosphatase in icteric and an-icteric biliary disease patients. IMJM. 2013;12(1). 